\title{
FLORA AND HABITAT OF POTATO PITS ON KAME HILLS IN NORTH-EASTERN POLAND
}

\author{
ANNA JUSTYNA KWIATKOWSKA-FALIŃSKA, JANUSZ BOGDAN FALIŃSKI \\ Faculty of Biology \\ Białowieża Geobotanical Station of Warsaw University \\ Sportowa 19, 17-230 Białowieża, Poland \\ e-mail: sekretariat.bsg@uw.edu.pl
}

(Received: March 13, 2006. Accepted: July 28, 2007)

\begin{abstract}
The research was carried out in north-eastern Poland in the vicinity of the village of Haćki $\left(52^{\circ} 50^{\prime} 00^{\prime}\right.$ 'N; $\left.23^{\circ} 11^{\prime} 20^{\prime \prime} \mathrm{E}\right)$. This area is distinguished by an exceptionally numerous agglomeration of kames (10). Previous archaeological and soil research showed that kames have been inhabited by man from the iron age, and that the following stages of colonization are reflected in three levels of fossil soils. In modern times local people use the base of kames for the storage of potatoes over the winter. The potato pits are a cultural curiosity found only in this area. They are dug out in the cohesive, fine-grained substratum, which is the building material of kames, down to 1.5-2 m deep.

Research plots (16) with a surface area of about $2-5 \mathrm{~m}^{2}$ were established in the potato pits in 1990. In the summer of the same year 16 phytosociological surveys were performed and soil samples taken. The investigated habitats are characterized by very low humidity. The concentration of carbon in the samples from potato pits dug out at the foot of a kame hill (the site of a settlement in the past) results probably from the occurrence of soil from the Roman period. At the present time the pits are covered by poor ruderal flora (approx. 10 species in one phytosociological survey). It is distinguished from other communities of such type by a low participation of species occurring in the xerothermic grasslands.
\end{abstract}

KEY WORDS: ruderal flora, history of colonization, flora of kames.

\section{INTRODUCTION}

Among the kame areas of north-eastern Poland, the kames of Równina Bielska (Bielska Plain) are distinguished by their agglomerated character and significantly smaller size (Ber 2005). An exceptionally numerous agglomeration is located in a kettle hole in the region of Haćki $\left(52^{\circ} 50^{\prime} 00^{\prime \prime} \mathrm{N} ; 23^{\circ} 11^{\prime} 20^{\prime \prime} \mathrm{E}\right)$. It is a unique area in respect of geomorphological, geological and lithological features. Small kames (from 0.1 to $0.3 \mathrm{~km}^{2}$ ) found in this area have different forms (kame hills and ridges), but uniform geological structure. Irrespective of the geomorphological form, they are characterized by steep slopes. Due to well-outlined landform edges they determine a remarkably prominent element of the landscape (Kondratiuk 1995; Kmieciak 2001; Brud 2001; Brud and Kupryjanowicz 2002; Ber 2005). Kames are built of a thick layer of fine-grained sand sediment constituting, unlike other types of sand, a cohesive substratum.

The region of Haćki is also of great cultural and historical significance. From archaeological research carried out in this area, it results that the slopes of the kettle hole, kame hills and ridges were occasionally used by man as early as at the decline of the stone age. In the bronze age the region of present day Haćki was occasionally inhabited. Permanent colonization began in the early iron age. The following stage of use took place in the early and late period of Roman influence (1st-4th century AD). The intensive use of the kame hills began in the early Middle Ages (6th and 7th century AD). Since the 9th century the whole area of the kettle hole and kames in Haćki has been under intensive settlement activities (Bluszcz and Pazdur 1993, Kobyliński 1990a, b; Pazdur et al. 1993; Szymański 1970, 1976; Kobyliński and Szymański 2005).

From the settlement of man on Równina Bielska (Bielska Plain), xerothermic grasslands from the class Festuco-Brometea and the order Festucetalia valeriacae were the seminatural vegetation related with kame hills and other kame forms (Kwiatkowska-Falińska and Faliński 2005a, b, 2007).

It should be highlighted that in north-eastern Poland such vegetation has been of secondary character for a long time. The Puszcza Bielska (Bielska Forest) formerly overgrowing this area had to regress because of the colonization wave. In the 15 th century it was already a deforested land (Wiśniewski 1964). According to Faliński (1972), the xerothermic grasslands (which in this area are the "plant 
indicators of kames") testify also to the prolonged presence of man.

The grasslands overgrew the kames' slopes and plateau, used up to the 1970s as intensive pastures. Unified, in respect of phytosociology, the character of the xerothermic grasslands results from the identical base present in all stands, and the same method of their use (Faliński 1972).

Transformations in the xerothermic grasslands are a consequence of differences in the intensity, and differences between the former and present method of use of soil by man. The more gentle slopes of kame ridges were used in past times as arable soil, and those more steep as pastures. The past hunger for arable land also resulted in the ploughing up of the foot of the slopes.

However, in the 1970s only the lowest parts of slopes were ploughed. Their plateau and steep slopes were overgrown with xerothermic grasslands. In some grasslands evidence of previous ploughing was found in the form of parallel furrows. In the later period some stands became forested with pine, and sometimes alder, larch or hemlockspruce (Faliński and Falińska-Kwiatkowska 2005a, b).

A special type of use practiced only in the area of Równina Bielska, and a local cultural curiosity, is the excavation of pits at the foot of kame hills for the storage of potatoes. This type of use has survived up to the present time (Fig. 1). Native people long ago tested the usefulness for such a purpose of the dry and cohesive substrata of which kames are built. In fine-grained sands with an admixture of dust, it is possible to dig out shallow "cellars" with walls that do not slide or require boarding. This type of excavations are to be found nowhere else except the kame hills of Równina Bielska. A considerable part of xerothermic grassland stands has been diminished in this way. Besides, the natural land form has also been disturbed.

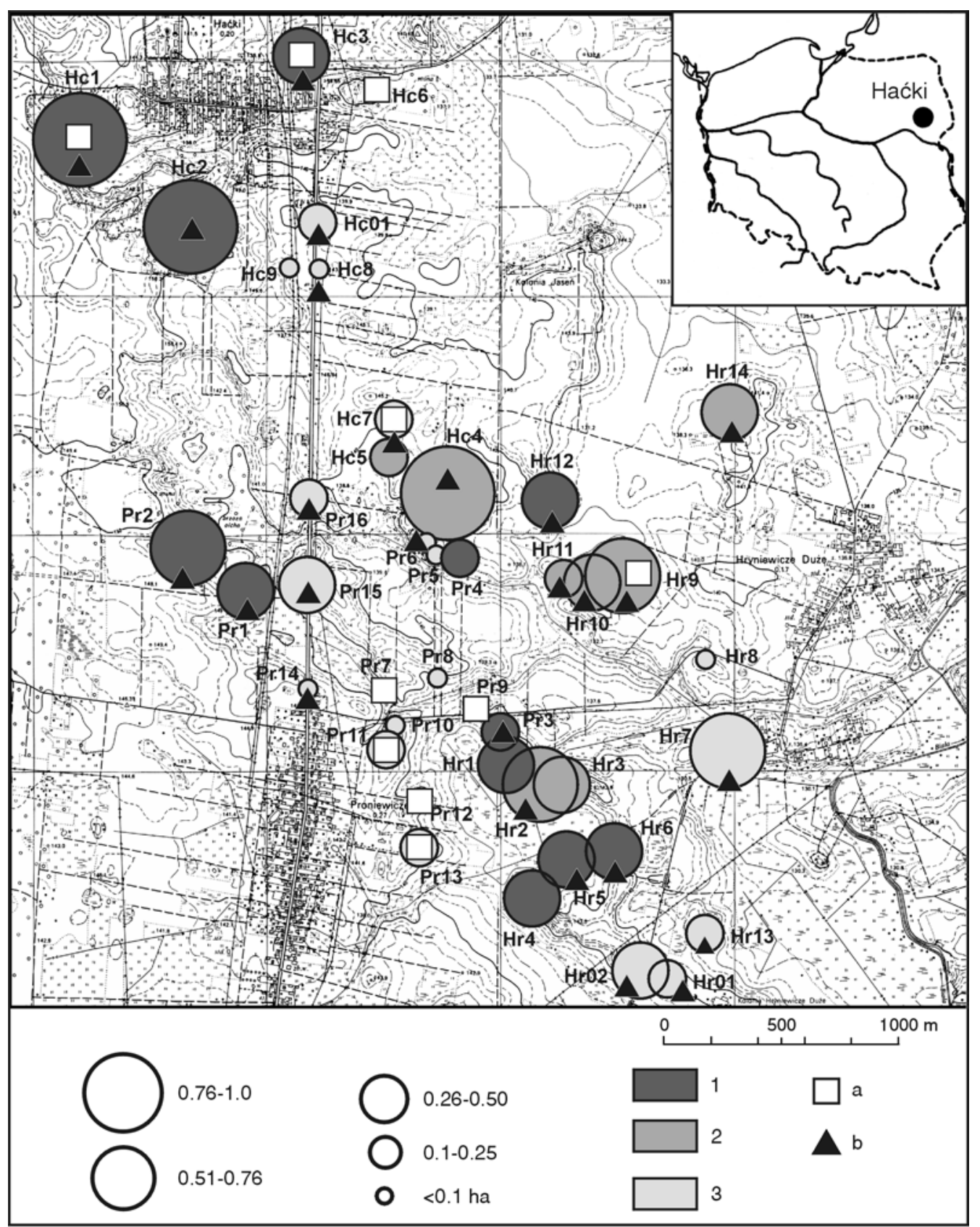

Fig. 1. Use of kame hills on the Równina Bielska (Bielska Plain) (1970): a - storage of potatoes; b - other (exploitation of mineral aggregate, cattle pasturage, forestation); the grasslands: 1 - big patches of xerothermic grassland; 2 fragments of patches; 3 - clumps of xerothermic species. Circles - size of area (in ha). 
These special microhabitats, formed by man at the foot of kame hills, became the objects of research. The habitat and flora covering the pits for the storage of potatoes were studied.

The purpose of the research was to answer the question of whether the specific ruderal flora is related to the special habitat, and whether this method of use can be determined as a foot-hold for further expansion of ruderal plants into the habitat of xerothermic grasslands.

The work was completed after the death of professor Janusz Faliński, and is based on his unpublished phytosociological surveys, which are archived in the Białowieża Geobotanical Station of Warsaw University in the file entitled by the author, "Ruderalization of grasslands".

\section{MATERIAL AND METHODS}

The plots were established in 1990 in the pits for potatoe storage dug out at the foot of ten kame hills and ridges (Fig. 2). The hills were located on Równina Bielska in the region of the village of Haćki (Hc 1, 3, 6, 7). The pits, dug out most often to a depth of 1.5-2 m, had a rectangular shape, with a surface area of about 2 to $5 \mathrm{~m}^{2}$. The size of the research plots was the same as the surface area of the pits.
The research was carried out on 16 objects situated at the foot of kame slopes with southern (series $S-8$ plots) and northern (series $\mathrm{N}-8$ plots) exposition. In the summer of 1990 Prof. J.B. Faliński performed phytosociological records using the Braun-Blanquet method.

In the same year, in August, samples of soil were taken from each surface. The samples were analysed by Jawiga Józefowicz-Kotlarz from the Institute of Soils of the University of Nicholas Copernicus in Torun. The samples were tested to determine ( $\%$ of dry mass): loss on roasting, carbon and nitrogen, and the relation of $\mathrm{C}$ to $\mathrm{N}$. Beside that, the soil reaction $\left(\mathrm{pH}\right.$ in $\mathrm{H}_{2} \mathrm{O}$ and $\left.\mathrm{KCl}\right)$ and the percentage of hygroscopic water were determined.

\section{RESULTS}

Microhabitats formed as a result of excavation of the pits at the foot of kame hills are characterized by alkaline reaction of the bases and very low humidity. The majority of investigated objects are remarkably dry during the summer. In most pits the content of hygroscopic water does not exceed $0.5 \%$ in the summer. Among objects examined with respect to humidity, three plots can be distinguished $(14 \mathrm{~N} 15 \mathrm{~N} 16 \mathrm{~N})$. They are characterized by the several ti-
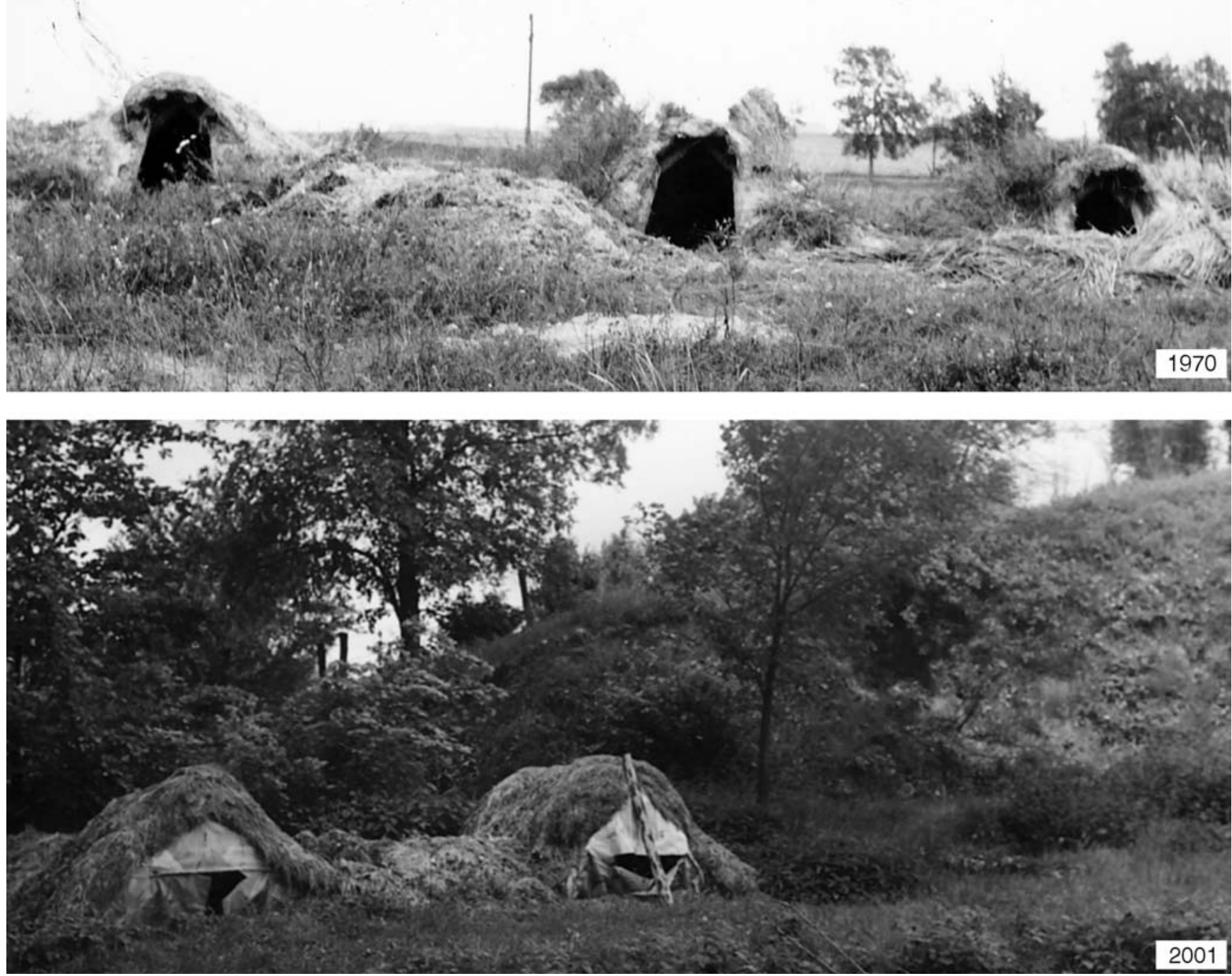

Fig. 2. Pits for the storage of potatoes: 1972 (Proniewicze) and 2001 (Haćki). Photo J.B. Faliński. 
TABLE 1. The dug out pits for potatoes - chemical and physical characteristics of the soils.

\begin{tabular}{|c|c|c|c|c|c|c|c|}
\hline Plots & $\mathrm{A}(\%)$ & $\mathrm{C}(\%)$ & $\mathrm{N}(\%)$ & $\mathrm{C}: \mathrm{N}$ & $\mathrm{pH}\left(\mathrm{H}_{2} \mathrm{O}\right)$ & $\mathrm{pH}(\mathrm{KCl})$ & $\mathrm{H}_{2} \mathrm{O}(\%)$ \\
\hline $1 \mathrm{~S}$ & 1.44 & 0.50 & 0.048 & 10.4 & 8.03 & 7.68 & 0.29 \\
\hline $2 \mathrm{~S}$ & 1.31 & 0.42 & 0.033 & 12.7 & 8.28 & 7.74 & 0.29 \\
\hline $3 \mathrm{~S}$ & 1.15 & 0.35 & 0.027 & 13.0 & 8.50 & 7.84 & 0.27 \\
\hline $4 \mathrm{~S}$ & 1.88 & 0.55 & 0.051 & 10.8 & 8.31 & 7.66 & 0.33 \\
\hline $5 \mathrm{~S}$ & 1.36 & 0.36 & 0.029 & 12.4 & 8.28 & 7.62 & 0.41 \\
\hline $6 \mathrm{~S}$ & 1.52 & 0.35 & 0.035 & 10.0 & 8.25 & 7.62 & 0.41 \\
\hline $7 \mathrm{~S}$ & 1.92 & 0.54 & 0.054 & 10.0 & 8.06 & 7.67 & 0.38 \\
\hline $8 \mathrm{~S}$ & 1.24 & 0.27 & 0.028 & 9.6 & 8.32 & 7.75 & 0.43 \\
\hline $9 \mathrm{~N}$ & 1.51 & 0.42 & 0.041 & 10.2 & 8.09 & 7.56 & 0.46 \\
\hline $10 \mathrm{~N}$ & 1.69 & 0.51 & 0.040 & 12.8 & 8.20 & 7.62 & 0.40 \\
\hline $11 \mathrm{~N}$ & 2.17 & 0.73 & 0.047 & 15.5 & 8.05 & 7.47 & 0.46 \\
\hline $12 \mathrm{~N}$ & 2.18 & 0.76 & 0.075 & 10.1 & 7.96 & 7.51 & 0.45 \\
\hline $13 \mathrm{~N}$ & 2.80 & 1.02 & 0.089 & 11.5 & 8.05 & 7.49 & 0.56 \\
\hline $14 \mathrm{~N}$ & 10.39 & 5.77 & 0.346 & 16.7 & 7.64 & 7.22 & 1.72 \\
\hline $15 \mathrm{~N}$ & 14.18 & 6.74 & 0.538 & 12.5 & 7.15 & 6.80 & 2.27 \\
\hline $16 \mathrm{~N}$ & 20.84 & 9.90 & 0.899 & 11.0 & 5.73 & 5.73 & 3.35 \\
\hline
\end{tabular}

mes higher content of: hygroscopic water (from 1.72 to $3.35 \%)$, carbon $(5.77-9.90 \%)$ and nitrogen $(0.35-0.90 \%)$ when compared to all the others (Table 1).

In the phytosociological table these objects are distinguished by the high participation of liverworts, and a relatively high percentage of covering by Stellaria media (Table 2).

Even if the samples taken from plots 141516 are excluded from the analysis, the mean values for such features as hygroscopic water, carbon and nitrogen are, for the 5 remaining plots from the northern series, always higher than for the southern series. Mean values calculated for these features amount to: $0.47 \%, 0.68 \%$ and $0.06 \%$, respectively.

The samples obtained from plots from the southern series (from $1 \mathrm{~S}$ to $8 \mathrm{~S}$ ) are characterized by the lowest mean values of the analysed features. The mean content of hygroscopic water amounts to: $0.35 \%$, carbon $0.41 \%$ and nitrogen $0.04 \%$.

All plots are almost completely covered with vegetation. A somewhat lower percentage of covering (from 40-90\%) was ascertained on the plots situated in the pits with a northern exposition. Those of southern exposition are abundantly overgrown by plants (covering: $80-100 \%$ ) and are somewhat more floristically rich. On one plot (surface area approx. $4 \mathrm{~m}^{2}$ ) from the series $\mathrm{S}$, over 10 species on average occur (10.5); and in the northern series - on average - one species fewer $\left(0.85 \mathrm{spec} . / \mathrm{m}^{2}\right)$. With the same quantity of sample $(\mathrm{n}=8)$ on plots with a southern exposition twice the number of ruderal species were found, on average, (from the classes Arrhethemisietes vulgaris, Epilobetea angustofolii and Stellarietea mediae) than in the areas with a northern exposition. The average number of ruderal species per plot amounts to 5.4 in the series $\mathrm{S}$, and 2.6 in the series N.

Only a small number of heliophilous and thermophilous species of xerothermic grasslands (from the classes Festuco-Brometea and Trifolio-Geranietea) occur in the transformed conditions of the habitat. On average, on each plot from 4.5 species in the series $\mathrm{S}$, to 3.9 species in the series $\mathrm{N}$ occur. Apart from the species from the above-mentioned groups, accompanying species are found sporadically (on average in both series approx. $1 \mathrm{spec}$./approx. $4 \mathrm{~m}^{2}$ ).

\section{DISCUSSION}

In the region of Haćki the pits for potato storage are dug out at the foot of the kame hills and are 1.5-2 m deep. Therefore, they should reach the level of the bedrock. However, the relatively high content of carbon in the analysed samples proved that excavation reached the level of the fossil soils connected with the primieval colonization in this region.

From among kames found on Równina Bielska, detailed archaeological and pedological documentation concerns only the kame (stand Hc1) Góra Zamkowa (Castle Hill). In this instance the subsequent periods of colonization are documented with archaeological findings (Szymański 1983; Kobyliński 1990a; Kobyliński and Szymański 2005). They are reflected in the soil research of the three separate topsoil levels (Kondratiuk and Banaszuk 1993; Banaszuk et al. 1996). Banaszuk and Kondratiuk (2005), ascertained that three generations of fossil soils, reflecting in their age the three phases of colonization, can be specified for this object. The deepest and the oldest is connected with the colonization of the Roman period, the middle level with the early-mediaeval phase of colonization $\left(6^{\text {th }}-7^{\text {th }}\right.$ century AD), and the youngest with the settlement phase of the $11^{\text {th }}$ century (Banaszuk and Kondratiuk 2005).

The authors' research resulted in finding that at the foot of the kame hill Gora Zamkowa the fossil soils are found in the layer located at a depth of $0.5-1 \mathrm{~m}$ (soil profile 2 ) and $1.2-2 \mathrm{~m}$ (soil profile 3 ). In the case of the soil from the Roman period, the content of carbon in 11 soil profiles examined by authors ranged from 0.53 to $1.12 \%$. In the level from the 6th-7th century, the content of carbon amounted to $0.71-2.37 \%$, and in the fossil soil from the 11th century, 0.57-2.39\% (Banaszuk and Kondratiuk 2005).

In all the samples taken from the potato-storage pits, the content of carbon ranges from 0.41 to $3.23 \%$. From among 16 pits, four were dug out at the foot of Gora Zamkowa in Haćki (samples: $1 \mathrm{~S}, 4 \mathrm{~S}, 7 \mathrm{~S}$ and $10 \mathrm{~N}$ ). Their depth (from 1.2 to $1.9 \mathrm{~m}$ ) and the content of carbon suggest the presence of the level of the oldest fossil soils. The content of carbon for these samples ranges slightly from 0.50 to $0.55 \%$, which overlaps the range found in soil samples from the Roman period. 
TABLE 2. The vegetation of pits for the storage of potatoes situated on the kame areas.

\begin{tabular}{|c|c|c|c|c|c|c|c|c|c|c|c|c|c|c|c|c|c|}
\hline \multicolumn{2}{|c|}{ Number of record } & 1 & 2 & 3 & 4 & 5 & 6 & 7 & 8 & 9 & 10 & 11 & 12 & 13 & 14 & 15 & 16 \\
\hline \multirow[t]{2}{*}{ Cover } & $\mathrm{c}$ & 80 & 100 & 100 & 100 & 90 & 90 & 90 & 80 & 90 & 70 & 70 & 80 & 80 & 40 & 60 & 90 \\
\hline & $\mathrm{d}$ & - & - & - & - & - & - & - & - & - & 20 & - & 20 & 15 & 70 & 50 & 40 \\
\hline \multicolumn{2}{|c|}{ Exposition } & $\mathrm{S}$ & $\mathrm{S}$ & S & S & S & $\mathrm{S}$ & S & $\mathrm{S}$ & $\mathrm{N}$ & $\mathrm{N}$ & $\mathrm{N}$ & $\mathrm{N}$ & $\mathrm{N}$ & $\mathrm{N}$ & $\mathrm{N}$ & $\mathrm{N}$ \\
\hline Surface & $\mathrm{m}^{2}$ & 5 & 2 & 4 & 4 & 4 & 4 & 4 & 4 & 5 & 3 & 4 & 4 & 3 & 4 & 4 & 4 \\
\hline
\end{tabular}

Species of classes: Artemisietea vulgaris, Stellarietea mediae:

\begin{tabular}{|c|c|c|c|c|c|c|c|c|c|c|c|c|c|c|c|c|}
\hline Urtica dioica & 4.4 & 3.3 & 1.2 & 4.4 & 2.3 & 4.4 & 2.2 & 4.4 & 4.4 & 4.4 & 4.3 & 4.3 & 2.2 & +.2 & . & . \\
\hline Artemisia vulgaris & . & + & + & + & + & + & 2.2 & 1.2 & + & + & + & . & . & 1.2 & . & + \\
\hline Oenothera biennis & . & 2.2 & 1.1 & +.2 & . & . & 1.2 & . & . & . & . & + & + & 1.1 & . & + \\
\hline Bertoroa incana & 1.2 & 1.2 & + & + & . & 2.2 & . & . & . & . & . & . & . & . & . & . \\
\hline Fallopia convolvulus & + & + & +.2 & . & +.2 & . & . & . & . & . & . & . & . & . & . & . \\
\hline Stellaria media & . & . & . & . & . & . & . & . & . & . & + & 1.2 & . & 1.2 & 2.3 & 2.3 \\
\hline Agropyron repens & + & + & . & + & . & + & . & . & . & . & . & . & . & . & . & . \\
\hline Chenopodium album & . & . & + & . & . & + & . & . & . & . & . & . & + & + & . & . \\
\hline Galeopsis tetrahit & . & . & . & . & . & 1.2 & + & . & . & . & . & 1.2 & . & . & . & + \\
\hline Conyza canadensis & . & . & . & . & . & . & . & + & + & . & . & . & . & + & . & . \\
\hline Myositis arvensis & . & . & . & . & . & + & . & . & . & . & . & . & + & . & . & . \\
\hline
\end{tabular}

Species of classes: Festuco-Brometea, Molinio-Arrhenatheretea:

\begin{tabular}{|c|c|c|c|c|c|c|c|c|c|c|c|c|c|c|c|c|}
\hline Galium mollugo & +.2 & 1.2 & +.2 & . & 3.3 & . & 3.3 & . & 1.2 & +.2 & + & . & +.2 & 1.2 & 1.2 & +.2 \\
\hline Artemisia campestris & + & +.2 & . & 2.2 & 1.2 & . & . & . & + & . & + & + & +.2 & . & . & . \\
\hline Dactylis glomerata & . & 1.2 & +.2 & . & . & . & . & . & . & +.2 & 1.2 & +.2 & + & 2.2 & . & 3.3 \\
\hline Convolvulus arvensis & . & 1.2 & 1.2 & . & . & + & +.2 & . & + & . & . & . & . & . & . & . \\
\hline Anthriscus sylvestris & . & . & . & . & . & . & . & . & . & . & + & . & . & + & 1.2 & + \\
\hline Pimpinella saxifraga & . & 1.2 & . & . & . & . & . & . & 1.1 & . & + & . & + & . & . & . \\
\hline Seseli annuиm & . & +.2 & + & . & . & . & . & . & . & . & + & . & . & . & . & . \\
\hline Knautia arvensis & . & 1.1 & 1.1 & . & . & . & . & . & 1.1 & . & . & . & . & . & . & . \\
\hline Festuca pratensis & . & +.2 & . & . & . & . & . & 1.2 & +.2 & . & . & . & . & . & . & . \\
\hline Poa pratensis & . & . & +.2 & . & . & . & . & . & . & . & . & . & . & . & . & + \\
\hline
\end{tabular}

Accompanying:

\begin{tabular}{|c|c|c|c|c|c|c|c|c|c|c|c|c|c|c|c|c|}
\hline Chelidonium majus & +.2 & . & . & +.2 & 3.3 & . & 2.3 & . & . & . & . & . & . & . & . & . \\
\hline Solanum tuberosum & . & . & . & 2.2 & 2.2 & . & . & 2.2 & . & . & . & . & . & + & . & . \\
\hline Rubus caesius & 2.3 & . & . & +.2 & . & . & . & . & . & . & . & . & . & . & . & . \\
\hline Angelica sylvestris & . & . & . & . & . & . & . & . & . & . & + & . & 2.1 & . & . & . \\
\hline Geum urbanum & +.2 & . & . & . & . & . & . & . & . & + & . & . & . & . & . & . \\
\hline Hepaticae: & . & $\cdot$ & . & . & . & . & . & . & $\cdot$ & . & . & . & . & 4.3 & 3.3 & 3.3 \\
\hline Musci: & . & $\cdot$ & . & . & . & . & . & . & $\cdot$ & 1.2 & . & 1.2 & 1.2 & . & 2.3 & . \\
\hline
\end{tabular}

rec. 1: Ballota nigra 1.2, Chaerophyllum sp. 1.2; rec. 2: Carduus acanthoides 1.1, Calamagrostis epigejos +.2 , Senecio jacobaea + ; rec. 3: Festuca rubra 2.3, Bromus inermis +.2 , Veronica spicata + , Thymus pulegioides +.2 , Fragaria vesca +.2 ; rec. 4: Chenopodium polyspermum + . Ballota nigra 2.3 ; rec. 5: Erigeron annuus 1.2; rec. 8: Sonchus oleraceus +; rec. 10: Taraxacum officinale +; rec. 12: Anthericum ramosum +.2 ; rec. 15: Lychnis flos-cuculi + , Ranunculus repens +.2

The vegetation of the potato pits is of ruderal character and is poor in species, i.e. only two species: Urtica dioica and Artemisia vulgaris. In the southern series Bertoroa incana, and in the northern Stellaria media occur in relative abundance and with a high frequency in all plots. The participation of grassland species from the class Festuco-Brometea, and meadow species from the class Molinio-Arrhenatheretea is specific to the investigated objects. Three species: Artemisia campestris, Dactylis glomerata and Galium mollugo attain a frequency higher than, or equal to $50 \%$.

The question of whether the flora of pits used for potatoes can be a foot-hold for the expansion of the xerothermic grasslands remains open. According to Faliński (1972), the ruderal flora poses a threat to the grasslands. The high light requirements of many ruderal species, and their ecological requirements in relation to habitat reaction, could support such a possibility. However, the presented results cannot be decisive for this issue, owing to the method of material collection used: there were no transects established projecting from the potato pits far inside the grassland. Due to this, the penetration of ruderal species into the xerothermic grassland has not been documented.

The excavation of pits transformed the new land form at the foot of kame hills. At this point the natural landscape in this area was disturbed. On the other hand, the occurrence of pits for potato storage proves the natural and cultural specificity of the area of Równina Bielska. And they are so special that the objects themselves are difficult to name, as they are not found anywhere else. To emphasise this fact I decided to use the word "pit".

From the point of view of the protection of xerothermic grasslands, the pits should be buried, and the exposed soil sown with diaspores of grassland species obtained from local populations. The question of whether or not we will diminish by this the cultural value of this area - I leave open. 


\section{ACKNOWLEDGEMENTS}

I am grateful to the staff of the Białowieża Geobotanical Station of Warsaw University, especially for Halina Kościelecka and Alicja Wiktoruk for their kindness and help during the preparation of this work.

\section{LITERATURE CITED}

BANASZUK H., BANASZUK P., KONDRATIUK P. 1996. Gleby na terenie prehistorycznej osady w Haćkach w okolicach Bielska Podlaskiego. Rocz. Glebozn. 67.1/2: 113-122. (in Polish with English summary)

BANASZUK P., KONDRATIUK P. 2005. Przekształcenie rzeźby i rozwój gleb w obniżeniu wokół "Góry Zamkowej”. In: Haćki. Zespół przyrodniczo-archeologiczny na Równienie Bielskiej. Faliński J.B. et al. (eds). Wyd. Białowieska Stacja Geobotaniczna UW. pp. 75-80. (in Polish)

BER A. 2005. Warunki geologiczne i geomorfologiczne powstania zespołu kemów w Haćkach. In: Haćki. Zespół przyrodniczo-archeologiczny na Równienie Bielskiej. Faliński J.B. et al. (eds). Wyd. Białowieska Stacja Geobotaniczna UW. pp. 9-29. (in Polish)

BLUSZCZ A., PAZDUR M.F. 1993. Datowanie metodą termoluminescencji zabytkowej ceramiki z grodziska w Haćkach na Podlasiu, Zeszyty Naukowe Politechniki Śląskiej. Seria: Matematyka - Fizyka, z. 70. Geochronometria 9: 47-67. (in Polish with English summary)

BRUD S. 2001. Objaśnienia do arkusza Bielsk Podlaski Szczegółowej mapy geologicznej Polski w skali 1:50 000. Centr. Arch. Geol. Państw. Inst. Geol. Warszawa. (in Polish)

BRUD S., KUPRYJANOWICZ M. 2002. Eemian Interglacial deposits at Haćki near Bielsk Podlaski: implications for the limit of the last glaciation in northeastern Poland. Geol. Quart., 46 (1): 75-80.

FALIŃSKI J.B. 1972. Potencjalna roślinność naturalna Wysoczyzny Bielskiej. Mater. Zakł. Fitosoc. Stos. UW Warszawa-Białowieża, 24: 1-23. (in Polish)

KMIECIAK M. 2001. Objaśnienia do arkusza Plutycze SMGP 1:50 000. CAG PIG, Warszawa. (in Polish)

KOBYLIŃSKI Z. 1990a. Early medieval hill forts in Polish lands in the 6th to the 8th centuries: problems of origins, function, and spatial organization. In: D. Austin, L. Alcock (eds), From the Baltic to the Black Sea. Studies in medieval archaeology, pp. 147-156. London.
KOBYLIŃSKI Z. 1990b. Chronologia osadnictwa w Haćkach na Podlasiu: przesłanki archeologiczne i radiowęglowe. Zeszyty Naukowe Politechniki Śląskiej. Geochronometria 6: 165-173. (in Polish with English summary)

KOBYLINSSKI Z., SZYMAŃSKI W. 2005. Pradziejowe i wczesnośredniowieczne osadnictwo w zespole kemów w Haćkach. In: Haćki. Zespół przyrodniczo-archeologiczny na Równinie Bielskiej. Faliński J.B. et al. (eds). Wyd. Białowieska Stacja Geobotaniczna UW. pp. 43-74. (in Polish)

KONDRATIUK P. 1995. Geologia, geomorfologia i gleby wokół prehistorycznej osady w Haćkach. In: Człowiek i Środowisko. Referaty i postery 44 Zjazdu Polskiego Towarzystwa Geograficznego, Toruń. (in Polish)

KONDRATIUK P., BANASZUK P. 1993. Interpretation of phosphorus concentration in archaeology in the light of soil science research. Archaeol. Pol. 31: 141-147.

KWIATKOWSKA-FALIŃSKA A.J., FALIŃSKI J.B. 2005a. Murawy kserotermiczne na Równinie Bielskiej - stan zachowania i zagrożenia. In: Haćki. Zespół przyrodniczo-archeologiczny na Równinie Bielskiej. Faliński J.B. et al. (eds). Wyd. Białowieska Stacja Geobotaniczna UW. pp. 84-93. (in Polish)

KWIATKOWSKA-FALIŃSKA A.J., FALIŃSKI J.B. 2005b. Zanikanie muraw kserotermicznych w Haćkach i ich ruderalizacja. In: Haćki. Zespół przyrodniczo-archeologiczny na Równinie Bielskiej. Faliński J.B. et al. (eds). Wyd. Białowieska Stacja Geobotaniczna UW. pp. 99-106. (in Polish)

KWIATKOWSKA-FALIŃSKA A.J., FALIŃSKI J.B. 2007. Conditions of the occurence of Anemone silvestris in a kettle hole in north-eastern Poland. Acta Soc. Bot. Pol. 76, 2: 133-140.

PAZDUR M.F., AWSIUK R., GOSLAR T., PAZDUR A. 1993. Chronologia radiowęglowa stanowiska w Haćkach, Zeszyty Naukowe Politechniki Śląskiej. Seria: Matematyka - Fizyka, z. 70. Geochronometria 9: 27-46. (in Polish with English summary)

SZYMAŃSKI W. 1970. Sprawozdanie z badań sondażowych grodziska w Haćkach, pow. bielski, przeprowadzonych w 1967 r. Rocznik Białostocki 9 (1968-1969): 388-392. (in Polish)

SZYMAŃSKI W. 1976. Komunikat o wynikach sondażowych badań grodzisk w Bielsku Podlaskim i we Wnorach-Wypychach gm. Kulesze Kościelne. Rocz. Białost. 13: 501-505. (in Polish)

SZYMAŃSKI W. 1983. Beiträge zum Problem der Entstehung von Burgen bei den Slawen. Archeologia Polona 21-22: 89-104.

WIŚNIEWSKI J. 1964. Rozwój osadnictwa na pograniczu polskorusko-litewskim. Acta Baltico-Slavica 1: 115-135. (in Polish) 